\title{
Landscape and biodiversity as new resources for agro-ecology? Insights from farmers' perspectives
}

\author{
Nicolas Salliou $^{1}$ and Cecile Barnaud ${ }^{1}$
}

\begin{abstract}
Pesticide reduction is a key current challenge. Scientific findings in landscape ecology suggest that complex landscapes favor insect pest biological control by conservation of natural enemy habitats. A potential agro-ecological innovation is to conserve or engineer such complex landscapes to reduce pesticide use. However, whereas the relevant resources are often well known in most natural resource management situations, potential resources involved in this innovation (natural enemies and the landscape) are not necessarily considered as resources in the eyes of their potential users. From the perspective that resources are socially constructed, our objective was to investigate whether and how these resources are considered by their potential users. To do so, we conducted research in an area specializing in tree-fruit (apple) production in southwestern France. This site was selected for its high pest incidence and high use of insecticides on orchards and, consequently, high stakes involved for any alternative. We conducted 30 comprehensive interviews with stakeholders (farmers and crop advisors) about their pest control strategies to explore their representation of their landscape and natural enemies. Our results show that natural enemies are considered by local stakeholders as public good resources, especially in the context of interventions by public institutions for their conservation, acclimation, and management. Farmers sometimes consider natural enemies as private goods when they can isolate the crop, enclosing it with nets or some other type of boundary. We also show that the landscape was not considered as a resource for biological pest control by conservation, but rather as a source of pests. We advocate for more research on the effects of landscapes on natural enemies, including participatory research based on dialogue among farmers, crop advisors, and scientists.
\end{abstract}

Key Words: biological control by conservation; collective action; landscape; mental model; uncertainty

\section{INTRODUCTION}

Farming practices are affecting biodiversity worldwide (McLaughlin and Mineau 1995). In particular, the use of chemicals as biocides has been under scrutiny because of its negative effects on biodiversity as well as on human health. In 2009, the European Commission established a directive aimed at achieving "sustainable use" of pesticides. In France, a national plan aims at a reduction in 50\% pesticide use by 2025 (Potier 2014). In this context, there is growing interest in research in agroecology and biodiversity-based agriculture that favors and makes use of biodiversity (Duru et al. 2015). Mobilizing natural processes involving natural enemies, i.e., the predators and parasites that reduce insect pest populations, is indeed a promising approach to reduce insecticide use in agriculture. Among the different existing approaches, biological control by conservation aims at protecting the natural habitats of natural enemy populations (Simon et al. 2010). Findings in landscape ecology suggest that complex landscapes can enhance biological control by conservation on farms through their positive effects on the natural ememies of insect pests (Bianchi et al. 2006, Rusch et al. 2010, Chaplin-Kramer et al. 2011). Here, complex landscapes are understood as agricultural patchy landscapes with high proportions of seminatural and wooded habitats (Bianchi et al. 2006).

Although such findings open up new possibilities for pest control practices at the landscape level (Cong et al. 2014), little is known about the concrete feasibility of such practices (Tscharntke et al. 2005, Schellhorn et al. 2015). Because agricultural landscapes are the outcome of many individuals' practices, a biological control strategy using complex landscape regulation might require coordination among these individuals. In line with this idea, Stallman (2011) suggests that, among different kinds of ecosystem services, biological pest control is potentially highly suitable for collective management at the landscape level. However, as Cong et al. (2014:54) write, "scant attention has been paid to the question of whether it is in the interest of farmers to manage habitats at the landscape scale for generating ecosystem services." Our objective is to fill this gap, i.e., to reach a better understanding of stakeholders' views about managing habitats to achieve biological pest control. In particular, we want to determine whether and in which conditions, from a stakeholder perspective, collective action could be an option for pest regulation at the landscape scale.

To address our aims, we used a theoretical framework combining Elinor Ostrom's framework on collective action with a constructivist perspective on resources. Ostrom studied collective action and self-organization among resource users in complex social-ecological systems (SESs; Ostrom 2009) as an alternative to top-down natural resource management (Holling and Meffe 1996). However, in Ostrom's work, the resource elements (water, forest, fisheries) are spontaneously considered as resources by their users. Indeed, she studied SESs in which such resources were well established and key to users' survival (Ostrom 1990). In our case, elements such as "natural enemies of insects" and "landscape" are only potential resources, and it is not known whether potential users consider them as resources. Such uncertainties are quite common in the field of agro-ecological design innovation, where resources and users are often not predefined (Berthet 2013). Thus, we suggest adding a constructivist perspective on resource qualification to Ostrom's framework. By constructivism, we mean that people use their experience to make meaning out of the world around them (Piaget 1967). They build their own "mental models," defined as "personal, internal representations of reality that people use to 
interact with the world around them" (Jones et al. 2011). The construction of these representations is influenced by individuals' personal history and their interactions with their social and physical environment. In this regard, whether or not something is considered a resource by an individual is the result of a social construction. At the cognitive level, the concept of resource is seen as a relational concept (Kebir 2006): an individual perceives an object in the environment as a resource when his or her mental model integrates interactions with this object and relates it to a benefit. This constructivist approach is significantly different from a naturalistic view on resources, which describes them as objective elements of reality (Kebir 2006, Labatut 2009). Within the diversity of SES approaches (Binder et al. 2013), this constructivist approach offers an original addition to existing SES frameworks. It enlarges the framework to include resources that might not yet exist or that are in the process of emerging as resources in people's opinions.

Furthermore, Ostrom's framework distinguishes different types of resources in terms of their subtractability and excludability (Ostrom 2009). A resource is subtractable if, when someone uses it, there is less for someone else. A resource is excludable if someone can easily prevent someone else from using it (Ostrom 2009). Ostrom's work stresses that different types of resources imply different kinds of management strategies.

Here, our objective is to analyze local stakeholders' perspectives on the potential of innovative pest management strategies based on collective action at the landscape level. We first present our case study and methodology: semidirected interviews and mental models elicitation in an apple production area in southwestern France. We then analyze how stakeholders integrate their environment in their actual pest management strategy: whether they consider the landscape and natural enemies of insects as resources for pest management, and what the characteristics (subtractability and excludability) of such resources would be (see Fig. 1). Finally, we discuss the scope and limitations of our research.

Fig. 1. Two-step theoretical approach to explore the social construction of a resource. (1) In this example, the hedgerow and natural enemies are resources because they are perceived as bringing a pest-regulating benefit. (2) From interviewee perception and speech, we analyze excludability and subtractibility of resources because these factors orient toward management possibilities.

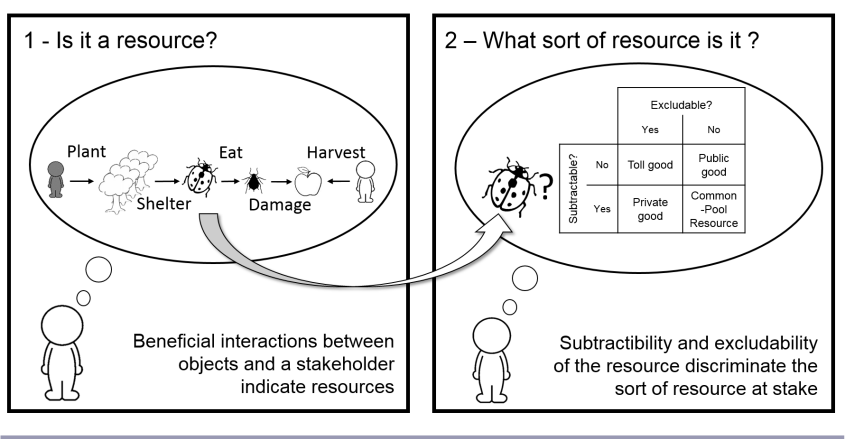

\section{METHODS: COMPREHENSIVE INTERVIEWS AND MENTAL MODELS}

The study area, located in southwestern France close to the Tarn and Aveyron rivers, is dominated by orchards (mainly apples) and cereal production. This area was particularly interesting for our investigation because tree-fruit crops are capital intensive. Because pest damage can have dramatic economic impacts, many farmers tend to rely on heavy chemical spraying. This area was also chosen on the basis of several local stakeholders showing interest in innovations related to biological control.

We conducted 30 individual interviews with 13 fruit growers, three livestock breeders, three cereal growers, two market gardeners, six crop advisors, and three landowners (mostly retired farmers). Farmers were selected to cover the diversity of production systems in the area. Each interview followed a comprehensive interview approach, i.e., a semidirected and open-ended form of interview that lets interviewees freely express their views (Kaufmann 2011). This method fit our approach, which aimed to explore how interviewees organize their pest management strategy in their mind. Each interview consisted of three steps: (1) a general description of the interviewee's actual and past activities, (2) a description of the interviewee's strategy regarding pest management, and (3) the interviewee's representation of landscape elements and natural enemies in his or her pest management strategy, if it was not mentioned spontaneously in the interview.

We followed this procedure for all stakeholders, even though landowners tended to have a very limited strategy toward pests because their income was not derived mainly from farming. A Google map was provided to help the interviewees discuss the influence of their environment.

Several methods for eliciting people's mental models have been developed in the field of natural resource management. Mental models are increasingly used where there is a growing need to take into account a plurality of values and goals linked to a given resource (Jones et al. 2011). Mental models are recognized for their relevance in gaining insight into the cognitive structures that frame people's interactions with complex and dynamic environments and in exploring how these structures may differ between individuals (Jones et al. 2014). We chose to use mental models because we wanted to explore whether local stakeholders' representations indicated key interactions associating natural enemies or the landscape with some benefit. From the diversity of approaches, we chose an indirect elicitation method (Jones et al. 2011). This means that we recorded each individual's interview and translated it into a conceptual map representing the interviewee's mental model of pest management. Concretely, we used Cmap software to design the conceptual model (Novak and Cañas 2008) and followed the ARDI (actors, resources, dynamics, interactions) ontology that represents social-ecological systems by focusing on the actors in the system, the resources they use, the dynamics of these resources, and the interactions among all of these elements (Etienne et al. 2011). An example is provided in Fig. 2.

Following our two-step theoretical framework for resource construction (Fig 1.), we analyzed each interview in two steps. 
Fig. 2. Example of a mental model for a crop advisor in tree-fruit production using the ARDI (actors, resources, dynamics, interactions) ontology. Light blue $=$ agents; green $=$ resources. Arrows with text indicate the nature and orientation of the interaction between elements of the mental model.

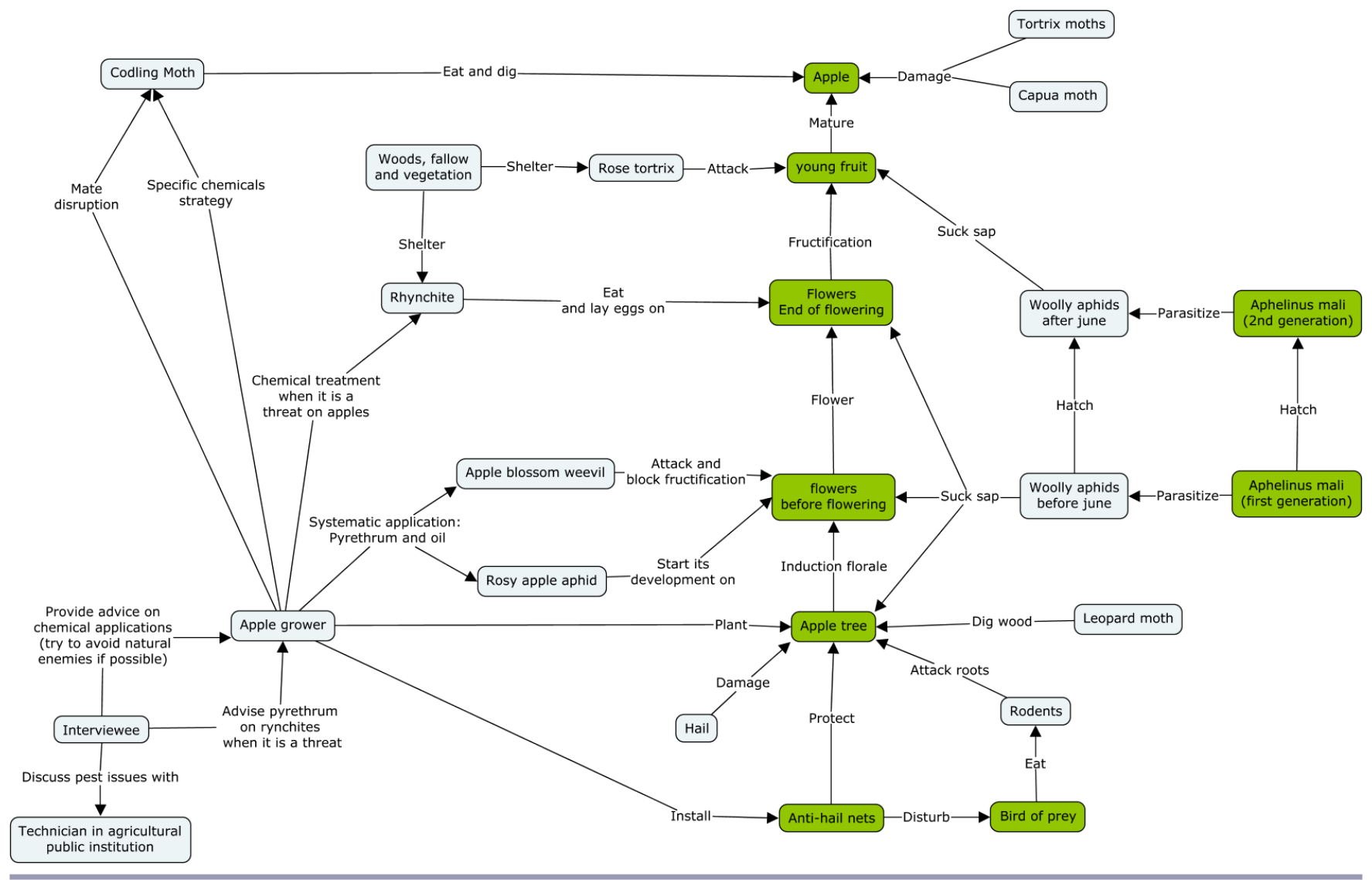

1. During mental model elicitation, we considered a given object as a resource when there was an interaction corresponding to a benefit relation with the object. As an example, regarding the interaction showing that Aphelinus mali parasitizes woolly aphids (Fig. 2), Aphelinus mali is considered a resource because it brings a benefit by reducing a pest on apples. These figures allowed us to evaluate the importance of landscape and natural enemies of insects as resources both quantitatively (how many times they were mentioned) and qualitatively (how they were mentioned).

2. The qualitative analysis of the interview recordings allowed us to understand further how and why landscape elements and natural enemies were considered resources (i.e., how these resources were socially constructed) and what kind of resources they would be in terms of subtractability and excludability.

\section{RESULTS}

The results are presented in two steps. We first describe how natural enemies were considered as resources. We then describe how the landscape was considered.

\section{Natural enemies as resources}

Of the 30 interviewees, 20 mentioned natural enemies of insects in their pest management strategies. We summarized the natural enemies mentioned, the pests on which they have an effect, and the social-ecological interactions with which they are associated in the interviewees' mental models (Table 1). Twelve different natural enemies were mentioned, and three natural enemies constitute more than half of all instances: Aphelinus mali, which parasitizes sap-sucking woolly aphids; ladybugs, which eat aphids; and predatory mites, which eat European red mites. Whereas the majority of crop advisors' mental models contain three to five instances of different natural enemies interacting with pests, farmers' mental models contain between zero and three instances. Of the 43 instances of natural enemies in all interviews, more than half (24) came from crop advisors.

In the following subsections, we analyze how and why these natural enemies are considered as resources by the interviewees, i.e. how these resources have been socially constructed. Among the 12 different natural enemies mentioned, we identified six different processes of social construction, detailed below.

Integrated pest management through public policies promotes natural enemies as a key resource

Seven mental models mentioned predatory mites as a natural enemy (Table 1). Three stakeholders indicated that this natural enemy was developed through public policies promoting integrated pest management (IPM) practices in the 1980s and 1990s. For example, one landowner stated, "The evolution 
Table 1. Characteristics of natural enemies mentioned during individual interviews as resources involved in pest control.

\begin{tabular}{|c|c|c|c|}
\hline $\begin{array}{l}\text { Natural enemy mentioned by } \\
\text { interviewees (family, species, and/or } \\
\text { common name) }\end{array}$ & $\begin{array}{l}\text { Mentioned effect on pest by } \\
\text { interviewees }\end{array}$ & $\begin{array}{l}\text { Number of interviewees } \\
\text { mentioning (stakeholder type) }\end{array}$ & Social-ecological interactions involved \\
\hline Aphelinus mali & $\begin{array}{l}\text { Parasitizes Eriosoma lanigerum } \\
\text { (woolly aphid) }\end{array}$ & 10 (7 farmers, 3 crop advisors) & $\begin{array}{l}\text { Acclimated natural enemy; renewed } \\
\text { care after pesticide ban }\end{array}$ \\
\hline Coccinelidae (ladybugs) & Prey on aphids & 10 (7 farmers, 3 crop advisors) & $\begin{array}{l}\text { Anti-insect nets may interfere with } \\
\text { them; used as a marketing argument } \\
\text { in direct sales }\end{array}$ \\
\hline Phytoseiidae (predatory mites) & $\begin{array}{l}\text { Prey on Panonychus ulmi (European } \\
\text { red mite) }\end{array}$ & 7 (4 farmers, 3 crop advisors) & $\begin{array}{l}\text { Efficient regulation after integrated } \\
\text { pest management development }\end{array}$ \\
\hline Syrphidae (hoverflies) & Parasitize aphids & 3 ( 2 crop advisors, 1 farmer $)$ & $\begin{array}{c}\text { Simple mention of a regulation } \\
\text { benefit }\end{array}$ \\
\hline Neodryinus typhlocybae & $\begin{array}{l}\text { Parasitizes and preys on Metcalfa } \\
\text { pruinosa (citrus flatid planthopper) }\end{array}$ & 3 ( 2 crop advisors, 1 farmer) & Acclimated natural enemy \\
\hline Chrysopidae (lacewings) & Prey on aphids & 2 (1 crop advisor, 1 farmer) & $\begin{array}{c}\text { Anti-insects nets may interfere with } \\
\text { them }\end{array}$ \\
\hline Trichogramma ostriniae & $\begin{array}{l}\text { Parasitizes eggs of Ostrinia nubilalis } \\
\text { (European corn borer) }\end{array}$ & 2 (2 farmers) & $\begin{array}{c}\text { Sold for biological control by } \\
\text { augmentation }\end{array}$ \\
\hline Asobara japonica & Parasitizes Drosophila suzukii & 1 (crop advisor) & $\begin{array}{l}\text { Acclimation project studied by } \\
\text { researchers }\end{array}$ \\
\hline Aphidoletes aphidimyza (aphid midge) & Preys on aphids & 1 (farmer) & $\begin{array}{c}\text { Simple mention of a regulation } \\
\text { benefit }\end{array}$ \\
\hline $\begin{array}{l}\text { Rhagonycha fulva (common red soldier } \\
\text { beetle) }\end{array}$ & Preys on aphids & 1 (farmer) & $\begin{array}{l}\text { Simple mention of a regulation } \\
\text { benefit }\end{array}$ \\
\hline Pear aphids & $\begin{array}{l}\text { Niche competition with Cacopsylla } \\
\text { pyri (European pear sucker) }\end{array}$ & 1 (farmer) & $\begin{array}{l}\text { Simple mention of a regulation } \\
\text { benefit }\end{array}$ \\
\hline Anthocoridae & Prey on Psyllidae & 1 (farmer) & $\begin{array}{l}\text { Simple mention of a regulation } \\
\text { benefit }\end{array}$ \\
\hline Forficula auricularia (earwig) & Preys on aphids & 1 (crop advisor) & $\begin{array}{c}\text { Anti-insects nets may interfere with } \\
\text { them }\end{array}$ \\
\hline
\end{tabular}

happened in the years 1985-1990, we adopted IPM. Today, red spiders [local name for European red mite] are not a problem anymore because we developed natural enemies."

No interviewee indicated the occurrence of any farmer involvement in this process of IPM development. This social construction is seen as a top-down process organized by public institutions and targeting crop advisors. In this regard, tree-fruit crop advisors had the highest quantity of natural enemies in their mental models. Furthermore, the mental models of 13 of the 21 interviewed farmers showed interactions with their crop advisors for their pest management. This illustrates a strong trend toward crop advisors holding specialized knowledge about natural enemies.

\section{Empirical experiences reveal natural enemies}

In parallel with IPM development, two fruit growers mentioned that they discovered and integrated natural enemies as a result of their field observations and experience. These fruit growers, who were active in 1991, mentioned an early frost that obliterated any hopes of an apple harvest. Consequently, they applied a minimal chemical treatment strategy. Even without treatment, they observed no European red mite damage on apple leaves. This event convinced these farmers about the efficiency of predatory mites. One fruit grower stated, "You realized that there were no more spiders because they had been preyed on by predatory mites. So it's from there that it started to change."

The change mentioned was that they let predatory mites regulate red mites, whereas chemical applications were previously almost systematic. Nowadays, this predatory mite resource is so obvious for controlling European red mites that many farmers mention it as an element of the past without mentioning it in their actual pest management strategy. When they recounted this experience, the interviewees made no mention of public IPM policies, even though they were occurring at the same time. The interviewees might have been influenced by these IPM policies, but it was nevertheless their own observations and experience that mattered for the social construction of this resource.

Natural enemies as resources in reaction to chemical product bans Ten of the 30 mental models contain Aphelinus mali, a natural enemy parasitizing woolly aphids (Table 1). Woolly aphids were apparently not a problem for most fruit growers until the pesticide vamidothion was banned by public authorities in 2003. A crop advisor stated, "It has become difficult against woolly aphids because KILVAL [vamidothion] was prohibited, something external that until 2003 we did not think much about."

Five interviewees mentioned that local agricultural public institutions, fruit-selling companies, and a local experimental center financed by fruit growers monitored Aphelinus mali in fields and experimental plots in the region. Because the remaining chemical treatments were insufficient to control woolly aphids completely, the alternative was to rely more on parasitism by Aphelinus mali.

Natural enemies as resources against invasive pest pressure In the study area, eight interviewees involved in tree-fruit production mentioned the invasive pest Metcalfa pruinosa, an 
Table 2. Overview of social construction of resources identified.

\begin{tabular}{|c|c|c|c|c|}
\hline Type of resource & Social construction of resource & $\begin{array}{l}\text { Type of stakeholder for } \\
\text { whom it is a resource }\end{array}$ & $\begin{array}{l}\text { Interviewees mentioning the } \\
\text { social construction process }\end{array}$ & Type of good \\
\hline Natural enemy against invasive pests & $\begin{array}{l}\text { Study by research institutions; } \\
\text { acclimation by public institutions }\end{array}$ & Researchers, crop advisors & 3 crop advisors, 1 farmer & Public \\
\hline $\begin{array}{l}\text { Natural enemy as a tool within } \\
\text { integrated pest management } \\
\text { program }\end{array}$ & $\begin{array}{l}\text { Public policy for integrated pest } \\
\text { management development }\end{array}$ & $\begin{array}{l}\text { Administration, crop } \\
\text { advisors }\end{array}$ & 1 advisor, 1 landowner & Public \\
\hline $\begin{array}{l}\text { Natural enemy as secondary } \\
\text { solution to pesticide bans }\end{array}$ & $\begin{array}{l}\text { Pesticide ban by public authorities; } \\
\text { monitoring by technicians }\end{array}$ & $\begin{array}{l}\text { Crop advisors, fruit tree } \\
\text { growers }\end{array}$ & 2 crop advisors, 1 farmer & Public \\
\hline $\begin{array}{l}\text { Natural enemy as a symbolic } \\
\text { resource }\end{array}$ & Marketing argument & $\begin{array}{l}\text { Fruit tree growers involved } \\
\text { in direct sales }\end{array}$ & 2 farmers & Public \\
\hline $\begin{array}{l}\text { Natural enemy for biological control } \\
\text { by augmentation }\end{array}$ & $\begin{array}{l}\text { Companies selling natural enemies; } \\
\text { companies imposing natural } \\
\text { enemies in production contracts }\end{array}$ & $\begin{array}{l}\text { Farmers, grain companies, } \\
\text { sellers of natural enemies }\end{array}$ & 3 farmers & Private \\
\hline $\begin{array}{l}\text { Ecosystem and its global ability to } \\
\text { regulate pests }\end{array}$ & $\begin{array}{l}\text { Philosophical relationship to nature } \\
\text { and ecosystems }\end{array}$ & Farmers & 2 farmers & Public \\
\hline Pest isolation of a crop & $\begin{array}{l}\text { Installing a boundary limiting } \\
\text { insects' access to a crop (net, } \\
\text { greenhouse) }\end{array}$ & Farmers & 1 farmer, 1 landowner & Private \\
\hline
\end{tabular}

invasive pest from North America that started to proliferate in the 1990s in southern Europe. Three of those interviewees (one fruit grower and two crop advisors) mentioned Neodryinus typhlocibae as a natural enemy of Metcalfa pruinosa (Table 1). They explained how advisors from the local agricultural public institutions worked in collaboration with public researchers to take charge of the acclimation of this new natural enemy. Invasive pests may indeed be controlled thanks to the acclimation of new natural enemies when local natural enemies are absent or inefficient. However, of the six farmers who mentioned Metcalfa pruinosa, five of them did not mention the natural enemy. This acclimation process remained a process managed by public institutions without farmer involvement.

\section{Natural enemies for biological control by augmentation}

Three farmers mentioned the use of natural enemies by augmentation (Table 2), which is the practice of releasing extra natural enemies on a farm to boost their population (van Lenteren 2000). A market gardener explained that he bought natural enemies from a local company and released them in his greenhouses. According to the interviewees, a certain degree of crop isolation was required to ensure the efficiency of the release. In our example, the greenhouse covering created a boundary that prevented dilution of the natural enemies into the surroundings.

\section{Natural enemies as a symbolic resource in communication with} buyers

Some interviewees mentioned a very different kind of benefit that they derived from natural enemies, that is, their symbolic representation of environmentally friendly agriculture (Table 2). Two small-scale fruit growers selling their fruits directly to consumers at open-air markets explained the use of natural enemies as a symbol of their care for the environment. One fruit grower stated, "On my peaches and apples, I have lacewing eggs (...) and it is common I have them. In the open-air market they ask me: 'What is that?' 'Well, these are natural enemies; you shall not kill them. There are some chemical treatments that I don't use anymore because they used to kill them all."'
Fruit growers supplying longer supply chains did not mention such considerations because they had no direct connection with their consumers.

Qualifying resources by their subtractability and excludability Through our analysis of mental models and speech, we identified six paths through which natural enemies were conceived as resources. Five of these paths indicate that these resources are public goods in terms of their subtractability and excludability. Indeed, stakeholders did not mention any competition in their use, risk of scarcity (nonsubtractability), or action toward limiting their access to other potential beneficiaries (nonexcludability). The situation is substantially different, however, when natural enemies have to be bought and released for biological control by augmentation. This case revealed a situation in which natural enemies were a private good. When farmers released natural enemies, they explicitly tried to limit their neighbors' access by creating some kind of boundary (excludability). Furthermore, they mentioned a dilution risk, indicating the scarcity of natural enemies, and a potential loss if natural enemies visited their neighbors' crops instead of theirs (subtractability). These social construction processes are identified and their qualifications are summarized in Table 2.

\section{Landscape as a resource in pest management?}

As mentioned earlier, findings in landscape ecology suggest that complex landscapes can enhance the presence of natural enemies and therefore favor biological control by conservation (Thies and Tscharntke 1999). We next analyze whether the landscape was considered as a resource by the interviewees.

\section{Landscape is mainly regarded as a threat regarding pests}

Except for one farmer mentioning an on-farm hedgerow sheltering natural enemies, landscape elements were not mentioned by interviewees as having a beneficial influence on natural enemies. Almost half of the interviewees (14) even mentioned a negative effect of landscape elements that stimulate diverse pests (Table 3). Among these 14 interviewees, four advisors mentioned 10 instances and 10 farmers mentioned 15 instances. 
Table 3. Characteristics of landscape elements mentioned during individual interviews and their effect on insect populations.

\begin{tabular}{|c|c|c|c|c|}
\hline Landscape mentioned & $\begin{array}{l}\text { Effect on insect populations } \\
\text { mentioned }\end{array}$ & Effect on crops mentioned & $\begin{array}{c}\text { Number of } \\
\text { interviewees } \\
\text { mentioning } \\
\text { (stakeholder type) }\end{array}$ & $\begin{array}{l}\text { Effect on pest } \\
\text { risk mentioned }\end{array}$ \\
\hline $\begin{array}{l}\text { Uncultivated land and hedgerows, } \\
\text { especially with nettles and } \\
\text { blackberries; kiwi trees }\end{array}$ & Favor Metcalfa pruinosa & $\begin{array}{l}\text { Honeydew production favors } \\
\text { fungus damage on fruits }\end{array}$ & $\begin{array}{c}4 \text { (2 farmers, } 2 \text { crop } \\
\text { advisors) }\end{array}$ & Low \\
\hline Woods & Favor Rynchites spp. & Pierce fruits & 3 ( 3 crop advisors) & Low \\
\hline Hedgerows, woods, and fallows & Favor Drosophila suzukii & $\begin{array}{l}\text { Pierce and lay eggs in diverse fruits } \\
\text { (cherries, strawberries, raspberries) }\end{array}$ & $\begin{array}{c}2 \text { (1 farmer, } 1 \text { crop } \\
\text { advisor) }\end{array}$ & High \\
\hline Walnuts & Favor codling moths & Eat and tunnel inside apples & $\begin{array}{l}2 \text { (1 farmer, } 1 \text { crop } \\
\text { advisor) }\end{array}$ & Low \\
\hline $\begin{array}{l}\text { Absence of other orchards around an } \\
\text { orchard }\end{array}$ & $\begin{array}{l}\text { Limits general insect pest } \\
\text { pressure in the orchard }\end{array}$ & Fewer attacks on orchards & 2 (2 farmers) & Positive \\
\hline Peach orchards & $\begin{array}{l}\text { Source of Grapholita molesta } \\
\text { for neighboring apple orchards }\end{array}$ & Attack peaches and apples & 2 (2 farmers) & Low \\
\hline Uncultivated land & $\begin{array}{c}\text { Favors Archips rosana (rose } \\
\text { tortrix) }\end{array}$ & Attacks young fruits & 1 (crop advisor) & Low \\
\hline Acacia spp. hedgerow & $\begin{array}{l}\text { Favors Scaphoideus titanus } \\
\text { (American grapevine } \\
\text { leafhopper) }\end{array}$ & Attacks grapes & 1 (farmer) & Low \\
\hline Dead trees & Shelter Xyleborus dispar & Attacks weak orchard trunks & 1 (farmer) & Low \\
\hline Cornfields & $\begin{array}{l}\text { Source of corn borer attacks } \\
\text { on low apple-tree branches }\end{array}$ & Attacks apples on low branches & 1 (farmer) & Low \\
\hline Poplars and willows & Favor Zeuzera pyrina & Tunnel in young tree trunks & 1 (crop advisor) & Low \\
\hline Forests & $\begin{array}{l}\text { Favor Anthonomus pomorum } \\
\text { (apple weevil) }\end{array}$ & $\begin{array}{c}\text { Eat and lay eggs in apple flower } \\
\text { buds }\end{array}$ & 1 (farmer) & Low \\
\hline Malus spp. in hedgerows & Source of woolly aphids & $\begin{array}{l}\text { Suck apple sap; honeydew } \\
\text { production favors fungus damage } \\
\text { on fruits }\end{array}$ & 1 (crop advisor) & Low \\
\hline Wheat fields & $\begin{array}{c}\text { Flows of ladybugs in July after } \\
\text { harvest }\end{array}$ & No particular effect noted & 1 (farmer) & Neutral \\
\hline Meadows & Shelter ladybugs & No particular effect noted & 1 (farmer) & Neutral \\
\hline Hedgerows without Rosacea & $\begin{array}{l}\text { Shelter, feed, and provide egg- } \\
\text { laying sites for generalist } \\
\text { predators }\end{array}$ & Eat aphids sucking apple tree sap & 1 (farmer) & Positive \\
\hline
\end{tabular}

Serious damage to cherry trees was reported in the case of Drosophila suzukii (fruit fly). This means that these stakeholders perceived off-farm effects of the landscape, but mainly negative ones. Moreover, two advisors who visited farms with a diverse proportion of seminatural habitats mentioned no difference among these farms in pest pressure or natural enemy presence. Finally, advisors often expressed their disappointment regarding past experiences of planting hedgerows to stimulate natural enemies. A crop advisor stated, "It was very fashionable in the 1990s to establish hedgerows (...) there was a great push for integrated pest management and hedgerows to shelter a wide variety of things (...) everybody, including myself, thought the method had great potential to increase natural enemy populations, and many hedgerows were planted but many were not effective. There are even some places where hedgerows have been removed. What seems straightforward in the literature does not necessarily materialize in reality."

Even though the landscape was described as mostly enhancing pests, two fruit growers mentioned that a farm with neighboring fields that do not produce the same crop can be beneficial. One fruit grower noted, "Fifteen to 20 years ago, there were 110 ha of orchards around here, whereas now the area is much reduced... for a very, very long time I was under very, very strong pressure from pest insects."
In this regard, isolation of one's farm from neighboring fields producing the same crop can be a benefit because of reduced pest pressure. However, no growers mentioned actively seeking such a situation.

Isolation from pest-enhancing landscape stimulates an enclosure process

The practice of anti-insect nets to surround an orchard completely is on the rise in the area because it opens up the possibility for farmers to isolate their plots from external negative influences. According to a landowner, "More and more new plantations, and even old ones, are covered with anti-insect nets (...) I think this trend of using protection nets against insects will continue."

This practice creates a new resource: an air space surrounding the crop, limiting pest inflows. This enclosure of orchards with nets opens up new biological control strategies. This practice could limit the dilution effect of natural enemy releases. As one marketgardener farmer stated, "For this fly [Drosophila suzukii], I don't know any predators. If there were any, I would release them inside my nets. In this situation, I would be confident of my strategy."

This use of nets favors a strategy oriented toward privatization of the environment surrounding the crop, which can be complemented by an economic sector selling natural enemies. 


\section{Holistic perspective on pest control: a global ability of} ecosystems

Two interviewees had a holistic perspective on biological pest control. By holism, we mean that, for pest control, they rely more on the ecosystem as a whole than on specific parts of it. This holism is at the same time a philosophical stance toward an ecocentric view of nature, where all parts constituting this whole are in equilibrium, and human disturbance should consequently be limited. For example, one farmer stated, "We're not alone on Earth (...) animals have a right to live, and I think that if birds (...) and other organisms in the ecosystem that prey on leafhoppers were removed, we would be reliant on a lot more agro-chemical use.”

These individuals had ambivalent components in their mental model, indicating both a benefit and a cost. On this matter, the same farmer said, "Falcons eat my chicks but also eat field mice and snakes... it's the chain of life."

Accepting such ambivalence was not common among conventional farmers and crop advisors, who generally were more reluctant to rely on ecosystem services and related trade-offs. An advisor stated, "Natural processes can be random and I don't like being reliant on a parasitic wasp (e.g., Aphelinus mali) to control aphids. One day, these wasps will prevent me from spraying against acaris [mites], and this will cost me money."

Tolerance of ecological uncertainty and potential economic risk seems to be a key factor regarding ecosystem integration within farms.

\section{DISCUSSION}

Our study combined semidirected interviews and mental models to analyze stakeholders' representations of natural enemies and the landscape as resources for biological control. In this section, we first return to the relevance of our methodological approach, in particular the use of mental models. Second, we discuss some unexpected results: the emergence of marketing and privatization strategies in the field of biological control. Finally, in a speculation section, we discuss the implications of our findings for potential agro-ecological innovation consisting of managing the landscape collectively to reduce pest pressure.

\section{To what extent can mental models be used to study social- ecological systems?}

Our method for studying the social construction of resources involved two steps for each interviewee: a semidirected comprehensive interview followed by an indirect and graphical elicitation of the interviewee's speech in a mental model (Jones et al. 2011). This method proved useful because graphical elicitation provided an overview of all mentioned interactions and facilitated their qualification and quantification (Tables 1 and 3). We were consequently able to identify in detail the diversity of resources constructed by the interviewees. We revealed in particular the interviewees' diverse views about how and why natural enemies may be resources. We were also able to identify some "missing" interactions in mental models, i.e., when interactions we had expected to show up in some mental models were not present, such as the interaction between the landscape and natural enemies. However, the reach of our conclusions remains limited by the sample size of interviewees. A larger panel of interviewees, including, in particular, local public authorities, would have potentially enhanced the scope of our conclusions. Moreover, our qualitative approach focusing on mental models was not efficient to study stakeholders' representations of land-use patterns such as landscape composition and configuration, which are nevertheless essential in pest management. It would be interesting to combine our approach with complementary spatially explicit methods such as agent-based modeling (Cong et al. 2016).

Regarding mental model elicitation methodologies, there are debates among scholars about the efficiency of using indirect elicitation of interviewees' mental models. Jones et al. (2014) mention no significant difference between direct or indirect elicitation. Other authors mention the risk of individual interviewer bias in the case of indirect elicitation (Vuillot et al. 2016). Interviewer bias is certainly a risk to the accuracy of the mental model because an intermediary is added to the elicitation process. To avoid many of these bias issues, Grenier and Dudzinska-Przesmitzki (2015) propose a multistep elicitation method that may increase the accuracy of the process. In our case, however, we based our approach on the comprehensive interview approach, which recognizes intersubjectivity between the interviewer and interviewee (Kaufmann 2011). This interview approach considers that the interviewer's subjectivity does not have to be hidden or considered as a bias but is recognized as an integral part of the elicitation process. The semidirected, openended interview method invites the interviewer to have a benevolent posture toward the interviewee and to establish a safe environment that encourages the expression of individual thinking and sometimes confidential information. Grenier and Dudzinska-Przesmitzki (2015) also mention the importance of creating such an environment for mental model elicitation. This posture and interview approach fit our research agenda, which was an inductive exploration of stakeholders' mental models. We acknowledge that such research could have been undertaken without mental model elicitation and with a classical qualitative speech analysis, even though the graphical elicitation of mental models helped the quantification analysis. For nonexploratory research aimed at collecting mental models and treating the information mathematically, for example, by aggregating mental models in similar groups (Özesmi and Özesmi 2004, Vuillot et al. 2016), a direct and multistep elicitation is probably necessary.

\section{Revealing marketing and privatization processes around biological control resources}

Our detailed analysis of stakeholders' representations enabled us to reveal a diversity of resources at stake around biological control. Among these resources, two appeared to us as quite unexpected and yet potentially critical in the future. The first relates to the use of natural enemies as resources in marketing. When farmers' clients are sensitive to more environmentally friendly farming approaches, communicating about natural enemy care can result in significant added value. In this regard, Sigwalt et al. (2012) describe how some winegrowers planted 23 $\mathrm{km}$ of hedgerows to demonstrate to their clients their care for natural enemies and their willingness to decrease their pesticide use. In another context, Michel-Guillou and Moser (2006) demonstrate that farmers mostly adopt proenvironmental practices to comply with social pressure rather than to put their beliefs about the environment into practice. This situation was clearly occurring in our study for the farmers who mentioned this type of resource because their pest management strategy was not 
particularly caring for natural enemies. This situation shows the risk of abusive green marketing (or greenwashing) in agriculture (Northen 2011). Such abusive use could be seen as a tragedy of the commons in which the value of the symbolic resource may decline if overused.

The second type of resource is exclusion nets around orchards, which favor strategies of landscape privatization. As farmers perceive the landscape mostly as a threat regarding pests, the development of an exclusion technology is not surprising. This privatization by exclusion nets not only protects against negative landscape effects, but may also favor biological control by augmentation. Dib et al. (2010) confirm such complementarity between exclusion nets and natural enemy releases, but they also show that this approach has a negative effect on the conservation of active natural enemies within the orchards. The overall effect of these nets remains to be fully evaluated because a significant conservation trade-off seems at stake.

\section{Speculation: toward pest-suppressing landscape?}

The innovation underlying our study is the prospect that farmers could use landscape ecology findings to enhance biological control. The landscape as an alternative to pesticides appears to be a promising tool for policy makers. Policy makers are willing to invest in such innovation, and even agro-ecological reparceling, if it is scientifically demonstrated that it can ensure significant pesticide reduction (Potier 2014). The stakeholders' representations that we gathered do not currently seem favorable to such an innovation because many stakeholders perceive the landscape as offering enhanced pest threats rather than benefits. In addition, landscape ecology findings indicate very variable effects of landscape complexity on biological control (Bianchi et al. 2006). This uncertainty makes it difficult to deliver reliable recommendations (Tscharntke et al. 2005) because the effect of natural habitats for biocontrol can vary dramatically and may regularly fail to enhance biocontrol (Tscharntke et al. 2016). Moreover, the identified innovation of enclosing fields with nets probably favors an individual strategy, which is opposite to a landscape approach. Indeed, once a farmer has invested in such nets, he or she might be unwilling to contribute to the enhancement of natural habitats in the landscape because he or she would get no benefit from it. By not contributing, farmers with nets might reduce the landscape's complexity and thus reduce the regulation benefit others might receive from a pestsuppressing landscape.

\section{CONCLUSION}

Our objective was to elicit local stakeholders' perspectives on the landscape and natural enemies of insects as resources for innovative agro-ecological pest management. We considered resources as social constructions and, through individual interviews with a diversity of stakeholders, identified and qualified how natural enemies and the landscape were perceived, or not, as resources.

Public policies were especially important for favoring natural enemies as resources for farmers in biological control. They did so by promoting more ecological farming practices, banning harmful pesticides, and favoring acclimation of natural enemies. We found no such process for the landscape as a resource for biological control by conservation. On the contrary, farmers' perceptions of the landscape as a threat was significantly different from the perspective commonly found among landscape ecologists. This threat favored landscape privatization by the use of exclusion nets around crops to reduce exposure to pests.

Policy makers indicated their willingness to invest in landscape engineering if scientists could demonstrate the efficiency of landscape complexity in reducing pesticide use through enhanced biological control. Consequently, more research that clearly relates landscape complexity to biological control benefits for farmers is a key precondition for such agro-ecological innovation. In this regard, opening a dialogue between agricultural practitioners and landscape ecologists about the effect of the landscape on natural enemies might attenuate the ambiguity between their diverging representations.

\section{Responses to this article can be read online at: http://www.ecologyandsociety.org/issues/responses. $\mathrm{php} / 9249$}

\section{Acknowledgments:}

We gratefully acknowledge all stakeholders who gave time and energy for this research. We also thank the INRA SMACH Metaprogramme and the Midi-Pyrénées Region for financial support. Finally, we thank Martine Antona, Julien Blanco, and Gwen Christiansen for their advice.

\section{LITERATURE CITED}

Berthet, E. 2013. Contribution à une théorie de la conception des agro-écosystèmes: fonds écologique et inconnu commun. Dissertation. École Nationale Supérieure des Mines de Paris, Paris, France. [online] URL: https://pastel.archives-ouvertes.fr/ pastel-00874630/document

Bianchi, F. J. J. A., C. J. H. Booij, and T. Tscharntke. 2006. Sustainable pest regulation in agricultural landscapes: a review on landscape composition, biodiversity and natural pest control. Proceedings of the Royal Society B 273(1595):1715-1727. https:// doi.org/10.1098/rspb.2006.3530

Binder, C. R., J. Hinkel, P. W. G. Bots, and C. Pahl-Wostl. 2013. Comparison of frameworks for analyzing social-ecological systems. Ecology and Society 18(4):26. https://doi.org/10.5751/ ES-05551-180426

Chaplin-Kramer, R., M. E. O'Rourke, E. J. Blitzer, and C. Kremen. 2011. A meta-analysis of crop pest and natural enemy response to landscape complexity. Ecology Letters 14(9):922-932. https://doi.org/10.1111/j.1461-0248.2011.01642.x

Cong, R.-G., J. Ekroos, H. G. Smith, and M. V. Brady. 2016. Optimizing intermediate ecosystem services in agriculture using rules based on landscape composition and configuration indices. Ecological Economics 128:214-223. https://doi.org/10.1016/j. ecolecon.2016.05.006

Cong, R.-G., H. G. Smith, O. Olsson, and M. Brady. 2014. Managing ecosystem services for agriculture: Will landscapescale management pay? Ecological Economics 99:53-62. https:// doi.org/10.1016/j.ecolecon.2014.01.007 
Dib, H., B. Sauphanor, and Y. Capowiez. 2010. Effect of codling moth exclusion nets on the rosy apple aphid, Dysaphis plantaginea, and its control by natural enemies. Crop Protection 29(12):1502-1513. https://doi.org/10.1016/j.cropro.2010.08.012

Duru, M., O. Therond, G. Martin, R. Martin-Clouaire, M.-A. Magne, E. Justes, E.-P. Journet, J.-N. Aubertot, S. Savary, J.-E. Bergez, and J. P. Sarthou. 2015. How to implement biodiversitybased agriculture to enhance ecosystem services: a review. Agronomy for Sustainable Development 35(4):1259-1281. https:// doi.org/10.1007/s13593-015-0306-1

Etienne, M., D. R. Du Toit, and S. Pollard. 2011. ARDI: a coconstruction method for participatory modeling in natural resources management. Ecology and Society 16(1):44. https://doi. org/10.5751/ES-03748-160144

Grenier, R. S., and D. Dudzinska-Przesmitzki. 2015. A conceptual model for eliciting mental models using a composite methodology. Human Resource Development Review 14 (2):163-184. https://doi.org/10.1177/1534484315575966

Holling, C. S., and G. K. Meffe. 1996. Command and control and the pathology of natural ressource managment. Conservation Biology 10(2):328-337. http://dx.doi.org/10.1046/ j.1523-1739.1996.10020328.x

Jones, N. A., H. Ross, T. Lynam, and P. Perez. 2014. Eliciting mental models: a comparison of interview procedures in the context of natural resource management. Ecology and Society 19 (1):13. https://doi.org/10.5751/ES-06248-190113

Jones, N. A., H. Ross, T. Lynam, P. Perez, and A. Leitch. 2011. Mental models: an interdisciplinary synthesis of theory and methods. Ecology and Society 16(1):46. https://doi.org/10.5751/ ES-03802-160146

Kaufmann, J.-C. 2011. L'entretien compréhensif: l'enquête et ses méthodes. Third edition. Armand Colin, Paris, France.

Kebir, L. 2006. Ressource et développement régional, quels enjeux? Revue d'Économie Régionale et Urbaine 5:701-723. https:// doi.org/10.3917/reru.065.0701

Labatut, J. 2009. Gérer des biens communs: processus de conception et régimes de coopération dans la gestion des ressources génétiques animales. Dissertation. École Nationale Supérieure des Mines de Paris, Paris, France. [online] URL: https://tel.archives-ouvertes. fr/pastel-00005220/document

McLaughlin, A., and P. Mineau. 1995. The impact of agricultural practices on biodiversity. Agriculture, Ecosystems and Environment 55(3):201-212. https://doi.org/10.1016/0167-8809 (95)00609-V

Michel-Guillou, E., and G. Moser. 2006. Commitment of farmers to environmental protection: from social pressure to environmental conscience. Journal of Environmental Psychology 26(3):227-235. https://doi.org/10.1016/j.jenvp.2006.07.004

Northen, G. 2011. Greenwashing the organic label: abusive green marketing in an increasingly eco-friendly marketplace. Journal of Food Law and Policy 7(1):101.

Novak, J. D., and A. J. Cañas. 2008. The theory underlying concept maps and how to construct and use them. Institute for Human and
Machine Cognition, Pensacola, Florida, USA. [online] URL: http://cmap.ihmc.us/docs/theory-of-concept-maps

Ostrom, E. 1990. Governing the commons: the evolution of institutions for collective action. Cambridge University Press, Cambridge, UK.

Ostrom, E. 2009. A general framework for analyzing sustainability of social-ecological systems. Science 325 (5939):419-422. https://doi.org/10.1126/science.1172133

Özesmi, U., and S. L. Özesmi. 2004. Ecological models based on people's knowledge: a multi-step fuzzy cognitive mapping approach. Ecological Modelling 176(1-2):43-64. https://doi. org/10.1016/j.ecolmodel.2003.10.027

Piaget, J. 1967. Logique et connaissance scientifique. Gallimard, Paris, France.

Potier, D. 2014. Pesticides et agro-écologie: les champs du possible. Ministère de l'agriculture, de l'agroalimentaire et de la forêt, Paris, France. [online] URL: http://agriculture.gouv.fr/telecharger/56000? token $=7 \mathrm{bf} 92926 \mathrm{cba} 72 \mathrm{dbc} 99 \mathrm{beeeef} 8758248 \mathrm{e}$

Rusch, A., M. Valantin-Morison, J.-P. Sarthou, and J. RogerEstrade. 2010. Biological control of insect pests in agroecosystems: effects of crop management, farming systems, and seminatural habitats at the landscape scale: a review. Pages 219-259 in Advances in agronomy. Volume 109. Academic Press, San Diego, California, USA.

Schellhorn, N. A., V. Gagic, and R. Bommarco. 2015. Time will tell: resource continuity bolsters ecosystem services. Trends in Ecology and Evolution 30(9):524-530. https://doi.org/10.1016/j. $\underline{\text { tree.2015.06.007 }}$

Sigwalt, A., G. Pain, A. Pancher, and A. Vincent. 2012. Collective innovation boosts biodiversity in French vineyards. Journal of Sustainable Agriculture 36(3):337-352. https://doi. org/10.1080/10440046.2011.654008

Simon, S., J.-C. Bouvier, J.-F. Debras, and B. Sauphanor. 2010. Biodiversity and pest management in orchard systems. A review. Agronomy for Sustainable Development 30(1):139-152. https://doi. org/10.1051/agro/2009013

Stallman, H. R. 2011. Ecosystem services in agriculture: determining suitability for provision by collective management. Ecological Economics 71:131-139. https://doi.org/10.1016/j. ecolecon.2011.08.016

Thies, C., and T. Tscharntke. 1999. Landscape structure and biological control in agroecosystems. Science 285(5429):893-895. https://doi.org/10.1126/science.285.5429.893

Tscharntke, T., D. S. Karp, R. Chaplin-Kramer, P. Batáry, F. DeClerck, C. Gratton, L. Hunt, A. Ives, M. Jonsson, A. Larsen, E. A. Martin, A. Martínez-Salinas, T. D. Meehan, M. O'Rourke, K. Poveda, J. A. Rosenheim, A. Rusch, N. Schellhorn, T. C. Wanger, S. Wratten, and W. Zhang. 2016. When natural habitat fails to enhance biological pest control - five hypotheses. Biological Conservation 244(B):449-458. https://doi.org/10.1016/ j.biocon.2016.10.001

Tscharntke, T., A. M. Klein, A. Kruess, I. Steffan-Dewenter, and C. Thies. 2005. Landscape perspectives on agricultural 
intensification and biodiversity - ecosystem service management. Ecology Letters 8(8):857-874. https://doi.org/10.1111/ j.1461-0248.2005.00782.x

van Lenteren, J. C. 2000. Success in biological control of arthropods by augmentation of natural enemies. Pages 77-103 in G. Gurr and S. Wratten, editors. Biological control: measures of success. Springer, Dordrecht, The Netherlands. http://dx.doi. org/10.1007/978-94-011-4014-0 3

Vuillot, C., N. Coron, F. Calatayud, C. Sirami, R. Mathevet, and A. Gibon. 2016. Ways of farming and ways of thinking: Do farmers' mental models of the landscape relate to their land management practices? Ecology and Society 21(1):35. http://dx. doi.org/10.5751/ES-08281-210135 